\title{
APLIKASI TEKNOLOGI FILTRASI MENUJU DESA MANDIRI AIR BERSIH DI SUMBERWUDI KARANGGENENG KABUPATEN LAMONGAN
}

\author{
Oleh : Sugito dan Pungut *)
}

\begin{abstract}
Abstrak
Wilayah desa Sumberwudi Karanggeneng Lamongan secara geografis termasuk daerah rawan air bersih. Kualitas air sumur payau terlebih pada musim kemarau.Usaha penyediaan air bersih menggunakan air sungai hanya dilakukan dengan pengendapan sederhana, sehingga kandungan lumpurnya tinggi dan berwarna kecoklatan. Kondisi air tidak memenuhi standar kesehatan. Pemerintah desa belum berupaya untuk menyediakan sarana air bersih baik aspek kuantitas, kualitas maupun kontinuitas. Untuk itu dilaksanakan penerapan teknologi filtrasi secara lengkap untuk mengolah air sungai menjadi air bersih yang layak konsumsi. Melalui program ini dapat menghasilkan air bersih yang memenuhi syarat kesehatan, memberdayakan masyarakat dalam sistem produksi dan pengelolaannya secara mandiri, membantu pemerintah untuk meningkatkan derajat ekonomi dan kesehatan masyarakat.Program diawali dengan proses sosialisasi kepada masyarakat. Penetapan lahan instalasi air bersih ditetapkan melalui koordinasi dengan pemerintah desa. Masyarakat terlibat langsung melalui proses pembelajaran dan pemberdayaan tentang proses penjernihan air. Proses pendampingan dilakukan agar masyarakat mampu melakukan proses produksi, pemeliharaan instalasi, dan mengelola menjadi usaha koperasi air bersih. Hasil program adalah sebuah instalasi penjernih air berupa bangunan utama bak sedimentasi dengan volume $20 \mathrm{~m}^{3}$, bak roughing filter volume $8 \mathrm{~m}^{3}$, bak filtrasi volume $4 \mathrm{~m}^{3}$, dan bak penampungan akhir volume $12 \mathrm{~m}^{3}$. Waktu tinggal air pada bak sedimentasi 4 jam menghasilkan air bersih 72 m3/hari dengan kualitas yang memenuhi syarat untuk melayani 150 $K K$.
\end{abstract}

Kata kunci : Air Bersih, Pemberdayaan Masyarakat, Teknologi Filtrasi

\section{PENDAHULUAN}

Kabupaten Lamongan bagian utara merupakan wilayah yang secara geologis dan geografis rawan air tawar. Sebagian wilayahnya merupakan tepi laut dimana budidaya tambak menjadi andalan usaha penduduk. Kondisi sumber air yang ada tidak layak digunakan sebagai sumber air bersih, karena airnya payau dan berwarna kehijauan.

Proses eutrofikasi terjadi akibat penggunaan pupuk yang berlebihan untuk usaha tambak, sehingga kandungan nitrogen dan phosfat tinggi. Proses industrialisasi, penggundulan hutan, mekanisasi pertanian, serta belum tertatanya sistem pengolahan limbah perkotaan terutama di sepanjang sungai menyebabkan kondisi air permukaan baik yang bersifat kualitas maupun kuantitas yang layak memenuhi kebutuhan manusia menjadi semakin langka. Kondisi air mengalir di badan-badan air kualitasnya sudah tidak memenuhi syarat sebagai bahan baku air minum, (Hadi, 2005).

$$
\text { Jumlah penduduk di desa }
$$

Sumberwudi pada tahun 2008 sejumlah 3050 jiwa yang terdiri dari $650 \mathrm{KK}$. Di wilayah desa Sumberwudi kecamatan Karanggeneng, terdapat 3 instalasi penjernihan air, yaitu milik bapak Taslan, ibu Maruah, dan milik kelompok RT di dusun Glogok. Kebutuhan air bersih desa Sumberwudi selama ini sebagian dipenuhi oleh tiga instalasi yang ada, namun hanya dapat memenuhi kurang lebih $250 \mathrm{KK}$ dengan kualitas air yang belum memenuhi syarat. Sedangkan sisanya untuk memenuhi kebutuhan air bersih harus membeli air PDAM di Kecamatan Sukodadi yang berjarak $12 \mathrm{~km}$. Hal ini sangat ironis dengan keberadaan desa Sumberwudi yang terletak di wilayah daerah aliran sungai Bengawan Solo. Air sungai ini dapat digunakan sebagai bahan baku kebutuhan air bersih.

Usaha penjernihan air selama ini diproduksi dengan menggunakan teknologi yang sangat sederhana yaitu dengan proses pengendapan saja. Proses yang dilakukan adalah air sungai dipompa dan ditampung pada bak pengendapan tanpa proses penyaringan maupun penambahan bahan kimia.

\footnotetext{
*) Dosen Teknik Lingkungan

Universitas PGRI Adi Buana Surabaya
} 
Setelah air mengendap, maka bagian permukaan yang jernih ditampung dan dijual kepada konsumen. Hal ini bila ditinjau dari proses pengolahan air bersih baru merupakan tahap sedimentasi untuk mereduksi lumpur.

Kualitas air hasil proses pengendapan yang dikonsumsi oleh masyarakat tersebut secara fisik menunjukkan indikasi kualitas yang rendah, yaitu berwarna kecoklatan yang berarti bahwa kandungan lumpurnya masih tinggi. Hasil uji laboratorium terhadap produk yang dijual tersebut adalah: $\mathrm{pH}=$ 7,$80 ;$ TDS $=1850 \mathrm{mg} / \mathrm{L} ;$ dan kekeruhan $=25$ NTU. Jadi hasil pengamatan secara fisis dan kimiawi didukung hasil uji laboratorium menunjukkan kualitas air yang dikonsumsi adalah tidak memenuhi syarat baku mutu air bersih sesuai dengan Permenkes No 907/MENKES/SK/VII/2002.

Berdasarkan uraian di atas maka penduduk desa Sumberwudi kekurangan air bersih karena belum ada proses penyediaan air yang benar dan profesional, sehingga distribusi air bersih juga tidak merata. Program ini bertujuan untuk menyediakan suatu instalasi penjernih air yang standar berbasis pembelajaran dan pemberdayaan masyarakat dengan memenfaatkan air sungai Bengawan Solo sebagai air baku. Manfaat dari program ini adalah meningkatkan produktivitas air bersih, pemanfaatan sumberdaya air permukaan, meningkatkan derajat ekonomi dan kesehatan masyarakat melalui usaha produksi air secara mandiri.

\section{KAJIAN PUSTAKA}

Aplikasi teknologi pengolahan air dalam program ini adalah upaya untuk memanfaatkan air sungai Bengawan Solo diproses menjadi air bersih yang dapat dikonsumsi. Masyarakat desa Sumberwudi belum memiliki pengetahuan tentang teknologi pengolahan air bersih. Oleh karena itu perlu dilaksanakan proses pengolahan air bersih dengan mengaplikasikan teknologi filtrasi lengkap yang dapat diterapkan melalui pembelajaran dan pemberdayaan masyarakat. Melalui program ini diharapkan upaya pemberdayaan masyarakat desa terjadi secara berkelanjutan sehingga dapat menyediakan air bersih secara mandiri.

\section{Unit-unit Pengolahan Air Bersih}

Kualitas air permukaan atau sungai dipengaruhi oleh daerah aliran sungai (DAS), sehingga mengandung mineral, bakteri, nutrient, pencemar dari limbah industri, domestik, dan pertanian. Perairan permukaan diklasifikasikan menjadi dua kelompok utama, yaitu badan air yang tergenang dan badan air yang mengalir,(Effendi,2003). Air permukaan terkontaminasi memerlukan pengolahan lengkap menjadi air bersih atau air minum. Pemanfaatan proses alami dengan Roughing Filter selain dapat menurunkan senyawa organik merupakan kelebihan dalam pengolahan air baku yang semakin tercemar akibat bahan organik,(Hadi,2005).

1) Bangunan Penangkap Air (Intake)

Intake merupakan suatu bangunan untuk menangkap atau mengumpulkan air. Fungsi intake adalah untuk menjaga kontinuitas pengaliran. Konstruksi intake harus memperhatikan fluktuasi muka air sungai, sistem pengurasan lumpur, pengamanan terhadap benda-benda terapung, dan alur sungai. Penanganan bangunan intake ditujukan untuk menjaga kuantitas, kualitas dan kontinuitas aliran. Kuantitas dan kualitas air yang dapat diproduksi bervariasi bergantung pada waktu, iklim, dan kondisi hidrologi lokal/daerah, (Obradovic \& Peter, 1998).

2) Bangunan Pengendap Pertama (Primary Sedimentation)

Primary Sedimentation berfungsi untuk mengendapkan partikel diskrit yang tidak berubah bentuk, ukuran, maupun beratnya selama pengendapan secara gravitasi. Kecepatan pengendapan partikel merupakan fungsi dari karakteristik air dan karakteristik partikel dalam air. Efisiensi proses diukur dari pemisahan kekeruhan yang bergantung pada diameter partikel dan kecepatan pengendapan. Kapasitas pengendap pertama tidak bergantung pada kedalaman bak, tetapi tergantung pada luas permukaanan bak dan kecepatan pengendapan partikel. Kondisi aliran laminer harus dijaga sehingga pengendapan secara gravitasi terjad secara optimal,(Sutrisno,2004 \& Triatmodjo, 2006).

3) Roughing Filter (RF)

Roughing Filter (RF) adalah suatu model dari pengendap dengan multi false bottom berupa kerikil yang dapat memisahkan partikel tersuspensi secara efektif,(Hadi,2005) . Proses utama yang terjadi pada RF adalah pengendapan partikel di permukaan bagian atas setiap media di dalam reaktor dan adhesi ke permukaan seluruh media. 
Keunggulan lain dari RF berupa terjadinya proses degradasi bio-kimiawi dalam bentuk penurunan senyawa organik dalam air baku sebesar 70\%,(Hadi,2005). Proses degradasi bahan organik dalam air memanfaatkan pertumbuhan mikroorganisme yang menempel pada media seperti koral dan batu kali,(Reynold \& Richards, 1996). Diameter kerikil yang digunakan pada $\mathrm{RF}$ lebih besar dari 2,0 $\mathrm{mm}$.

Salah satu model RF adalah Horizontal Flow Roughing Filter (HRF) seperti gambar 1. HRF memiliki kapasitas tampung lumpur yang besar. HRF dibagi dalam zona-zona dengan gradasi media dari ukuran besar ke kecil. Lebar box filter antara 2-5 $\mathrm{m}$ diisi dengan media kerikil dengan diameter 4-40 mm. Slope box filter sebesar 1\%. Kecepatan pengaliran antara $0,5-4 \mathrm{~m} / \mathrm{jam}$ tergantung kekeruhan awal air baku. Bila air baku sangat keruh, kecepatan $\begin{array}{lll}\text { maksimum } & 2 \mathrm{~m} / \mathrm{jam} \text {. }\end{array}$

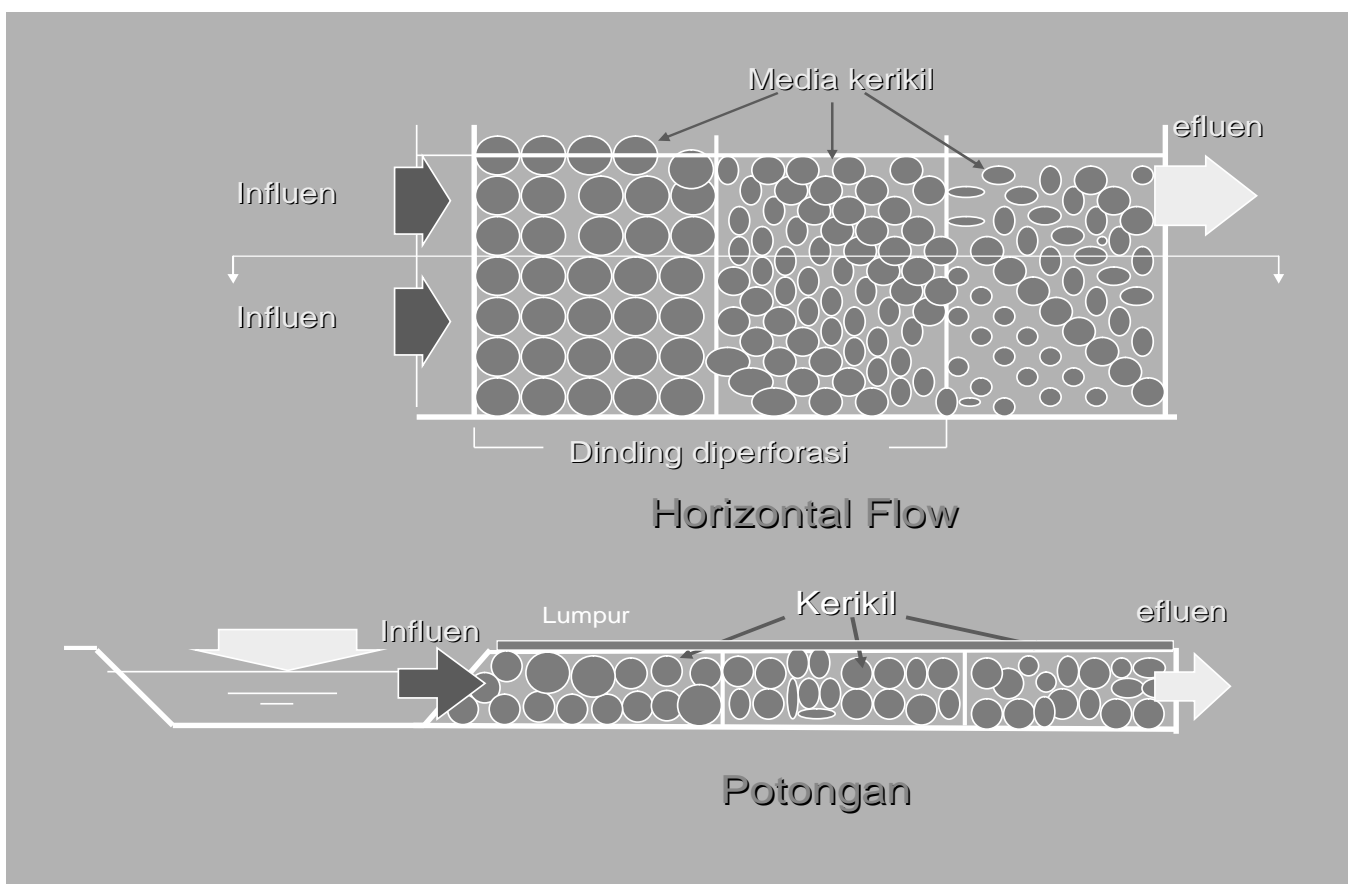

Gambar 1. Horizontal Flow Roughing Filter (Hadi,2005)

4) Koagulasi

Koagulasi merupakan proses pencampuran koagulan dalam air melalui pengadukan cepat. Dosis koagulan yang tepat dilakukan dengan Jar-test. Koagulan primer yang sering digunakan adalah Tawas, $\mathrm{Al}_{2}\left(\mathrm{SO}_{4}\right) .14$ $\mathrm{H}_{2} \mathrm{O}$ dalam bentuk serbuk atau cairan. Pembubuhan dosis koagulan dipengaruhi oleh $\mathrm{pH}$ air, kekeruhan, lama pengadukan, dan suhu air,(Hadi,2005). Hal yang harus diperhatikan pada pembubuhan koagulan adalah perpipaan yang mengalirkan bahan kimia tersebut agar tidak tersumbat,(Sutrisno,2004). Proses pembubuhan dapat dilakukan secara gravitasi atau menggunakan dosering pompa.
5) Flokulasi

Flokulasi merupakan proses pembentukan flok melalui pengadukan lambat, setelah proses koagulasi. Terdapat beberapa jenis flokulasi yaitu mekanis, hidrolis dan pneumatis. Flokulasi hidrolis dilakukan dengan memasang sekat yang diperforasi dan membatasi suatu kompartemen dengan kompartemen lain dibuat dengan mengatur gradien kecepatan yang makin menurun. Faktor-faktor yang berpengaruh pada pembentukan flok adalah kekeruhan, Suspended Solid, $\mathrm{pH}$, Alkalinity, lama pengadukan, dan bahan koagulan,(Sutrisno,2004)

6) Bak Sedimentasi II

Bak Sedimentasi II berfungsi mengendapkan flok dari pengadukan lambat dimana ukuran, bentuk, dan 

Kabupaten Lamongan

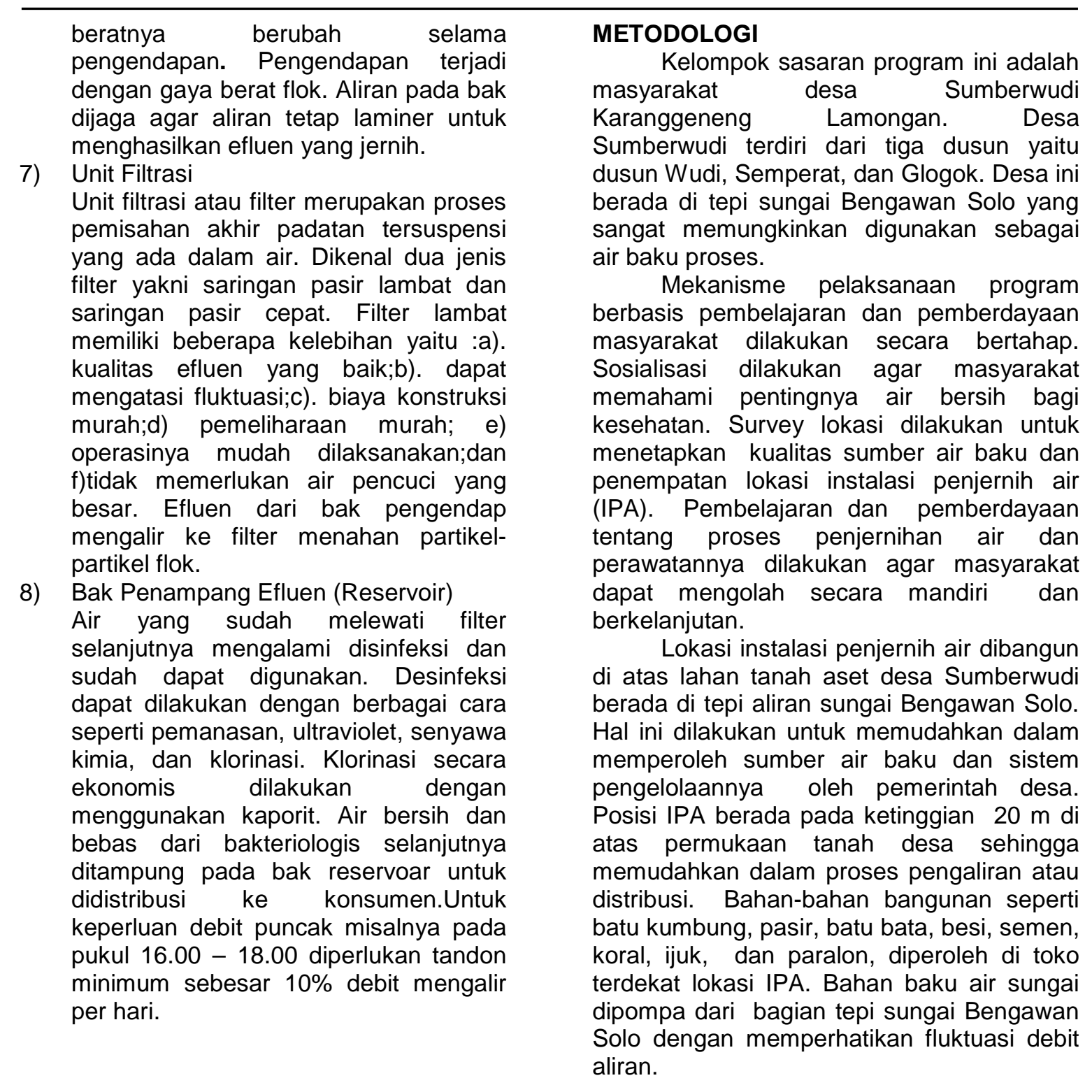




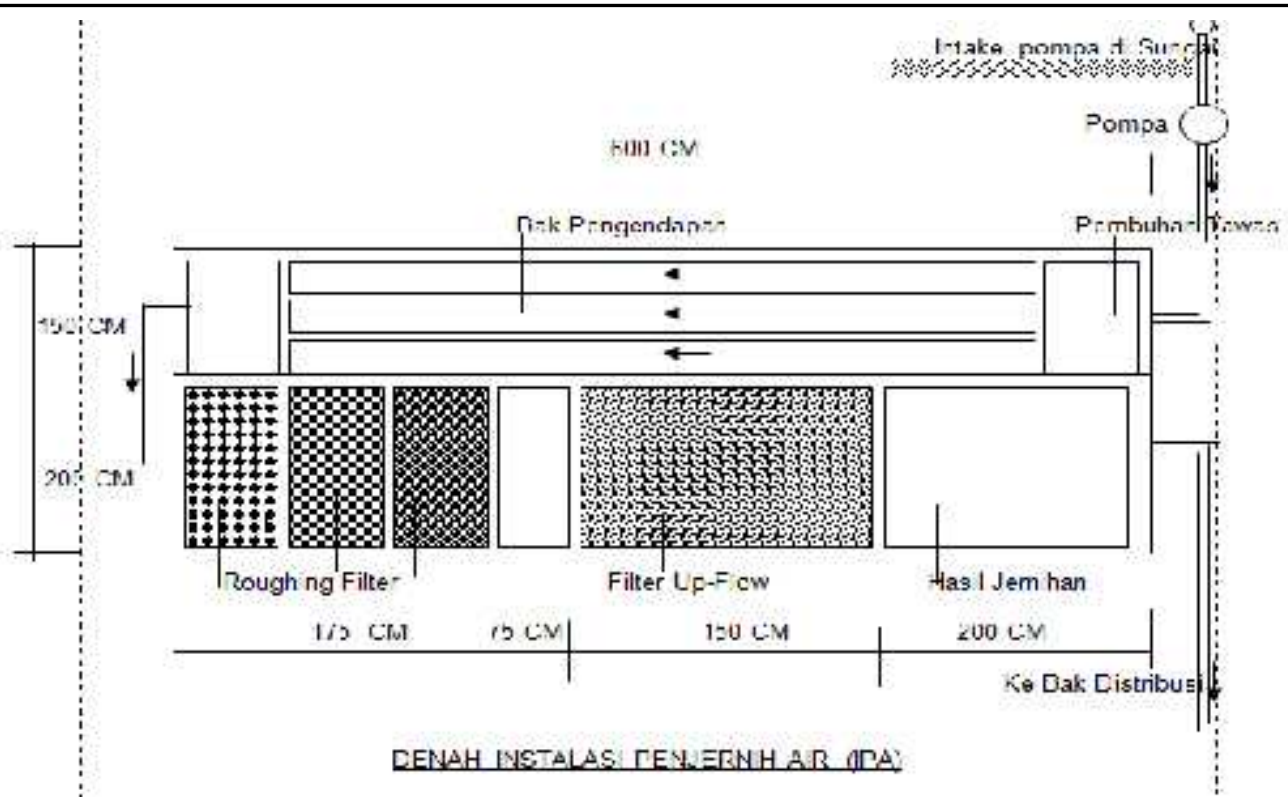

Gambar 2. Denah Instalasi Penjernihan Air (IPA)

Dimensi IPA ditetapkan berdasarkan kebutuhan air penduduk. Perhitungan debit produksi didasarkan pada jumlah penduduk yang akan dilayani untuk $150 \mathrm{KK}$. Kebutuhan air bersih ditetapkan sebesar 100 liter/orang/hari, dengan asumsi masingmasing KK terdiri dari 5 orang anggota keluarga maka dibutuhkan debit air bersih $75 \mathrm{~m}^{3} /$ hari. Berdasarkan perhitungan ini maka diperoleh dimensi IPA seperti pada gambar 2.

Pembangunan instalasi diawali dengan pemasangan pondasi menggunakan batu kumbung. Bangunan dasar bak menggunakan beton bertulang agar kualitas bangunan kuat karena menahan beban air yang berat. Dinding bak terbuat dari pasangan batu bata. Posisi bak sedimentasi dibangun di bagian atas dengan menggunakan plat beton. Hal ini dilakukan agar aliran menuju bak Roughing Filter dan Clarifier mengalir secara gravitasi. Bak Roughing Filter tersekat menjadi 3 (tiga) bagian diisi material batu koral dengan ukuran gradasi dari ukuran yang besar (2-3 $\mathrm{cm})$ menuju semakin kecil $(0,5-1 \mathrm{~cm})$. Material koral berada pada bagian tengah bak, berada di atas plat beton terpervorasi. Aliran upflow-downflow dipilih untuk memperoleh air produk yang jernih.

Proses pengolahan diawali dengan memompa air sungai Bengawan Solo ke bak sedimentasi. Aliran dijaga dengan kondisi laminer agar proses pengendapan optimal. Selanjutnya air menuju bak Roughing Filter untuk mereduksi bahan organik terlarut secara gravitasi dengan aliran upflowdownflow. Air terolah berikutnya menuju filter yang terdiri dari lapisan kerikil, pasir, ijuk yang telah dicuci. Produk air bersih ditampung pada reservoar atau bak penampungan akhir untuk diklorinasi sehingga bebas dari mikrobiologis. Air produk selanjutnya didistribusi kepada masyarakat pengguna dilakukan dengan sistem perpipaan.

\section{HASIL DAN PEMBAHASAN}

1. Hasil proses sosialisasi, pembelajaran dan pemberdayaan masyarakat

Keberhasilan suatu program dipengaruhi oleh proses sosialisasi kepada masyarakat. Sosialisasi dilaksanakan pada malam hari di balai desa Sumberwudi karena mengikuti kultur masyarakat, dimana pada siang hari warga masyarakat bekerja. Sambutan masyarakat desa sangat antusias terhadap program penyediaan air bersih yang akan dilaksanakan. Masyarakat sangat menginginkan air bersih yang berkualitas, tidak berhenti setelah pembangunan instalasi, namun juga sangat diperlukan keberlanjutannya untuk mempertahankan debit air yang dihasilkan sehingga dapat memenuhi kebutuhan yang diharapkan.

Pemerintah desa dan kecamatan sangat mendukung terhadap program penyediaan air bersih ini. Perusahaan Daerah Air Minum (PDAM) kabupaten Lamongan juga memberikan support 
karena perusahaaanya belum dapat memenuhi air bersih sampai pelosok desa yang ada. Selain itu program ini didukung oleh mitra yaitu CV Perkasa Agung sebagai suplayer bahan kimia. Program ini menjadi percontohan bagi desa lain di wilayah Lamongan terutama bagi desa-desa yang mengalami kesulitan air bersih.

Kesanggupan pemerintah daerah sebagai mitra merupakan bentuk kepedulian akan kemajuan desa di wilayahnya. Kegiatan ini akan membawa dampak terhadap kesehatan dan ekonomi wilayah. PDAM berperan sebagai pembina masyarakat dalam manajemen air bersih serta memberikan konsultasi teknis tentang teknologi penyediaan air bersih.

Proses pembelajaran dilakukan untuk memberikan bekal ilmu penyediaan air bersih kepada masyarakat. Materi pembekalan meliputi manfaat air bersih bagi kesehatan dan ekonomi, pembuatan IPA dengan teknologi filtrasi air, rancang bangun pembuatan instalasi, uji coba instalasi, evaluasi proses, pembenahan dan perawatan instalasi secara operasional. Aspek manajemen diberikan dengan tujuan agar masyarakat dapat mengelola instalasi dan sistem distribusi dalam bentuk koperasi air bersih.

Proses pemberdayaan dilakukan pada saat pembangunan instalasi IPA. Partisipasi masyarakat pada kegiatan pelaksanaan meliputi pembuatan konstruksi yang dilaksanakan dengan kerja bhakti. Partisipasi dana yang diwakili oleh lembaga mitra yaitu CV. Perkasa Agung berupa sumbangan material dan bahan kimia tawas untuk proses sedimentasi dan kaporit untuk desinfeksi. Partisipasi masyarakat diwujudkan dengan merelakan lahan tanah desa untuk dijadikan tempat instalasi pengolahan air, bak penampung bahan baku maupun produk jadi, serta pemasangan instalasi distribusi. Partisipasi kelompok sasaran untuk mengikuti pelatihan pengoperasian IPA, memelihara dan mengelola produk instalasi air bersih.

2. Bangunan fisik instalasi penjernih air Instalasi Penjernih Air (IPA) dibangun di atas tanah desa berada $50 \mathrm{~m}$ dari tepi sungai Bengawan Solo di dusun Wudi. Bangunan IPA terdiri dari bak penyadap air baku (intake), bak sedimentasi, bak Roughing filter, bak Filtrasi, bak reservoar, saluran distribusi, dan tandon air di wilayah permukiman dusun Sumberwudi. Proses pembangunan IPA dilakukan secara koordinatif oleh pelaksana dibantu mahasiswa KKN, serta masyarakat desa secara bergilir.

Hasil program adalah terbangunnya IPA yang terdiri dari bangunan utama bak sedimentasi volume $20 \mathrm{~m}^{3}$, bak Roughing filter volume $8 \mathrm{~m}^{3}$, bak filtrasi volume 4 $\mathrm{m}^{3}$, dan bak penampungan akhir volume $12 \mathrm{~m}^{3}$, seperti pada gambar 3 . Berdasarkan hitungan waktu tinggal air pada bak sedimentasi sebesar 4 jam, maka akan menghasilkan volume air bersih sebesar $72 \mathrm{~m}^{3} /$ hari dengan hasil yang memenuhi syarat kualitas air bersih. Debit sebesar ini dapat melayani sekitar 150 KK seperti pada perencanaan awal.
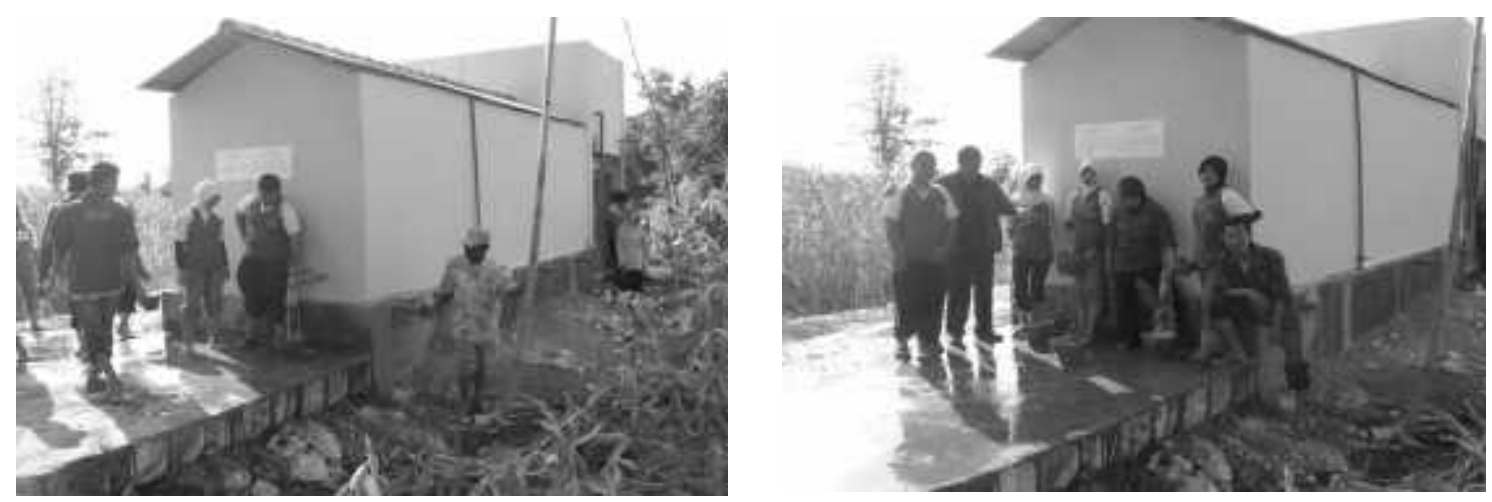

Gambar 3 Instalasi penjernih air menghasilkan air bersih

3. Kualitas air proses produksi

Kualitas air proses IPA berupa air bersih yang memenuhi syarat. Hasil pengamatan parameter utama secara fisik tidak berasa dan berbau. Uji laboratorium untuk konsentrasi $\mathrm{pH}=7,5$ ; TDS $=400 \mathrm{mg} / \mathrm{l} ;$ kekeruhan $=4 \mathrm{NTU}$. Secara fisis air proses menunjukan 
kualitas sangat bersih. Bila dibandingkan dengan kondisi air baku sungai Bengawan Solo sebelum diolah, maka terjadi penyisihan yang singnifikan.

Konsentrasi $\mathrm{pH}$ masuk dalam kriteria kualitas air bersih ( $\mathrm{pH}: 6,5 \mathrm{~s} / \mathrm{d} \quad 8,5$ ), removal TDS sebesar $78 \%$, dan kekeruhan sebesar $84 \%$. Hal ini menunjukan bahwa kinerja instalasi IPA yang dibangun termasuk kriteria baik. Pemanfaatan Roughing filter dalam instalasi ini sangat baik. Roughing filter selain berfungsi untuk membantu proses filtrasi awal, juga berfungsi untuk mendegradasi bahan organik terlarut dalam air, (Hadi,2005). Hal ini terjadi karena belum semua zat organik terlarut dapat mengendap pada bak sedimentasi. Proses ini memanfaatkan mikroorganisme yang tumbuh secara alami menempel pada dinding media roughing filter. Pertumbuhan mikroorganisme pisitif membentuk lapisan biofilm, (Reynolds \& Richards, 1996).

4. Keberlanjutan program

Keberlanjutan program kegiatan ini adalah memasyarakatkan teknologi tepat guna IPA sehingga menghasilkan air bersih yang memenuhi standar kualitas. Rekomendasi kepada PDAM dilakukan karena teknologi menghasilkan air proses yang memenuhi syarat. Hasil proses teknologi IPA didesiminasikan kepada kepala desa di wilayah Sumberwudi kecamatan Karanggeneng untuk diaplikasikan di wilayahnya.

Masyarakat desa memperoleh pelatihan tentang manajemen pengelolaan air bersih. Manajemen pengelolaan keberadaan IPA selanjutnya dilakukan oleh pemerintah desa bersama masyarakat untuk menjaga sustainabilitas effluen yang optimal. Untuk itu perlu dibentuk tim pengelolaan atau koperasi yang sudah disanggupi oleh kepala desa.

Daya dukung potensi ekonomi di desa Sumberwudi perlu ditingkatkan untuk kelangsungan operasiona IPA dalam jangka panjang. Potensi ekonomi desa Sumberwudi memiliki prospek yang baik karena terdapat beberapa jenis usaha yang membutuhkan air bersih, yaitu : Poliklinik, rumah sakit, praktek dokter, sekolah, pondok pesantren, bengkel, pasar desa, rumah makan, dan pertokoan. Oleh karena itu di masa yang akan datang instalasi perlu dikembangkan kapasitas debitnya untuk memenuhi kebutuhan yang harus tersedia sesuai perkembangan wilayah desa.

Penetapan harga jual air ditetapkan berdasarkan pada beaya produksi yang meliputi kebutuhan energi, tenaga kerja, beaya pengelolaan dan pemeliharaan. Selain itu juga memperhatikan kondisi ekonomi masyarakat konsumen untuk keberlanjutannya. Harga air bersih di desa sekitar Sumberwudi dengan sumber instalasi swadaya adalah sebesar $\mathrm{Rp}$ $2.000,-/ \mathrm{m} 3$. Sedangkan harga air bersih produksi PDAM kabupaten Lamongan sebesar terendah Rp. 1500,- dan tertinggi Rp. 2.290,-/m3. Untuk itu maka pengelola IPA desa Sumberwudi menetapkan harga jual air produksi kepada masyarakat tidak lebih dari Rp. 2.300,-/m3.

\section{KESIMPULAN}

Berdasarkan hasil proses dan pembahasan disimpulkan bahwa aplikasi teknologi filtrasi untuk penyediaan air bersih desa Sumberwudi Karanggeneng Lamongan berhasil dengan baik. Instalasi penjernih air menghasilkan air bersih yang memenuhi standar kesehatan. Debit air bersih sebesar $72 \mathrm{~m}^{3} /$ hari dapat mencukupi kebutuhan penduduk yang selama ini tidak terlayani secara kontinu. Operasional IPA secara berkelanjutan dapat menjaga kontinuitas ketersediaan air bersih bagi masyarakat. Melalui penyediaan air bersih maka kondisi ekonomi dan kesehatan masyarakat desa dapat meningkat.

\section{UCAPAN TERIMA KASIH}

Pada kesempatan ini penulis menyampaikan terima kasih yang sebesarbesarnya kepada DP2M DIRJEN DIKTI DEPDIKNAS melalui LPPM UGM Yogyakarta sebagai koordinator yang telah mendanai kegiatan ini berdasarkan No Kontrak 2289/PI/LPPM/2008 tanggal 2 April 2008.Terima kasih kepada Universitas PGRI Adi Buana Surabaya yang telah mendukung pelaksanaan program ini dalam bentuk KKNPPM. Tak terlupakan Direktur PDAM Kabupaten Lamongan, CV Perkasa Agung, Camat Karanggeneng, pemerintah desa dan masyarakat Sumberwudi serta para mahasiswa yang telah mendukung kegiatan ini. 


\section{DAFTAR PUSTAKA}

Effendi, Hefni.2002. Telaah Kualitas Air Bagi Pengelolaan Sumber Daya dan Lingkungan Perairan. Yogyakarya. Kanisius.

Hadi, Wahyono.2005. Perencanaan Bangunan Pengolahan Air Minum. FTSP ITS Surabaya.

Obdradovic, D. \& Lonsdale, P.1998. Public Water Supplay: Model Data and Operational Management. USA Taylor \& Francis Group.

Reynolds \& Richards.1996. Unit Operations and Processes in Invironmental Enginnering. Second Edition. PWS Publishing Company.

Santoso, Gempur dkk.2008. Buku Pedoman KKN-PPM. LPPM UNIPA Surabaya.

Triatmodjo, Bambang.2006. Hidraulika I. Yogyakarta. Beta Offset. 